\title{
ALLERGIC CONTACT CHEILITIS DUE TO LIPSTICK
}

\author{
Kus Harijanti* Yoli Sidharta Santosa ${ }^{* *}$
}

Keywords:

allergic cheilitis,

lipstick

\begin{abstract}
Allergic contact cheilitis is a common cause inflammation of the outer lip or vermillion margin. It is due to a type IV hypersensitivity reaction following contact with an allergen. Allergic contact cheilitis is more common in women than men. Lip cosmetics are the most common allergen source in women, while toothpastes allergy occur mostly in men. Purpose: To report the management of allergic contact cheilitis due to lip cosmetics. Case : A 22-years old woman complaint was dryness of the lips, cracking and peel off after using lip cosmetics since one week ago. Patient used new lips-cosmetics two weeks ago. No history to atopic allergy and no medication. Intra oral examination was normal. Management : patient was advised to avoid wearing lip-cosmetics. To relieve symptoms were given topical anti-inflammation non steroids, multivitamin and maintain to oral hygiene. Patient revered to patch testing. Patient had strongly positive result to the tested lip cosmetics. Patient were given topical anti inflammation steroids and from dermatology department were given antihistamine tablets. Conclusion : Patch testing is the key to this diagnosis and for determining of contact allergen.
\end{abstract}

\section{PENDAHULUAN}

Kontak alergi adalah tipe yang penting dari reaksi delayed type hypersensitivity, yang mana timbul setelah kulit atau mukosa kontak dengan alergen. Alergen tersebut mempunyai molekul yang kecil (picric acid, dinitrochlorobenzene, different herbal ingridients, kosmetik, beberapa obat-obatan, metals dan substansi yang lain). Sesudah diabsorbsi kedalam epidermis/epitel, substansi tersebut berikatan dengan protein sebagai karier dan menjadi immunogenic, kemudian terjadilah respon hipersensitivitas. Manifestasinya dapat berupa eritema dan edema pada kulit, kadang-kadang diikuti adanya vesikula yang meluas ${ }^{1}$.

Klasifikasi klasik hipersensitivitas dari Gell and Coombs tahun 1995 terbagi dalam 4 tipe yang telah direvisi oleh Janeway dan Travers yaitu reaksi tipe I disebut immediate hypersensitivity reactions atau anaphylaxis reaction yang melibatkan $\lg E$ yang menyebabkan aktivasi sel mast sehingga terjadi pelepasan histamine dan mediator lain dari sel mast dan basofil. Reaksi tipe II (cytotoxic hypersensitivity reactions) yang melibatkan antibody IgG atau IgM, yang terikat pada membrane dari antigen kemudian terjadi fiksasi komplemen. Reaksi tipe III ( immunecomplex reactions) yang melibatkan kompleks antigen-antibodi dalam kapiler, selanjutnya terjadi fiksasi komplemen. Reaksi tipe IV (delayed hypersensitivity reactions, cellmediated immunity) diatur oleh chemokin dan sitokin karena stimulasi Th1 sel oleh antigen. Antigen pada jaringan local diproses oleh Antigen Presenting Cells dan dipresentasikan pada molekul MHC class II 2.

Reaksi hipersensitivitas tipe IV juga disebut sebagai hipersensitivitas lambat karena

*Lecturer of the Department of Oral Medicine, Faculty of Dentistry, Universitas Airlangga, Indonesia ${ }^{* *}$ Post-graduate Student of the Department of Oral Medicine, Faculty of Dentistry, Universitas Airlangga, Indonesia Korespondensi: oralmedicineairlangga@gmail.com 
manifestasi klinis timbul 24 hingga 72 jam setelah tubuh kontak dengan antigen atau alergen. Manifestasi dalam rongga mulut dari reaksi ini, antara lain cheilitis, gingivitis, stomatitis, perioral dermatitits, burning mouth syndrome, reaksi lichenoid, dan orofacial granulomatosis. ${ }^{3}$ Reaksi hipersensitivitas tipe IV dapat terjadi pada pasien yang sebelumnya kontak dengan antigen tertentu dan dengan demikian telah terjadi sensitisasi. Studi menunjukkan bahwa setelah fase sensitisasi, CD4+ mensekresi berbagai macam sitokin yaitu TNF-à dan TNF-ß yang akan mempengaruhi ekspresi molekul adhesi (E-selectin, ICAM-1, VCAM-1) pada sel endotel pembuluh darah dari kulit yang kontak dengan alergen ${ }^{1}$.

Allergic contact cheilitis merupakan allergic contact dermatitis yang mengenai bibir. Hal ini merupakan reaksi dari hipersensitivitas tipe IV yang melalui kontak dengan alergen dan biasanya merupakan keradangan yang mengenai vermillion border atau kulit disekitarnya (peri-oral). Allergic contact cheilitis dapat mengenai laki-laki maupun wanita, orang dewasa lebih sering terkena dari pada anak-anak. Pada wanita biasanya penggunaan dari lipstick dan pada pria biasanya pada penggunaan pasta gigi, pada orang tua karena konsumsi obat-obatan. Dental material dan produk oral hygiene dapat mengenai semua umur. Alergen yang umumnya dapat menimbulkan cheilitis adalah metal seperti nickel, fragrance/flavourings atau preservative ${ }^{4}$.

Gambaran klinis dari allergic contact cheilitis adalah keradangan pada vermillion atau kulit disekitarnya, bisa bibir bawah/atas atau keduanya dan bisa melibatkan sudut mulut. Pada vermillion tampak kemerahan, kering, deskuamasi dan berfisur. Allergic contact cheilitis jarang melibatkan mukosa labial. Pasien mengeluh kaku, gatal, panas dan sakit pada bibirnya. Kunci untuk menegakkan diagnosis adalah pacht-test yang dihubungkan dengan riwayat timbulnya penyakit dan diduga sebagai alergen (misalnya penggunaan kosmetik/pasta gigi). Terapi dari allergic contact cheilitis adalah menghindari allergen ${ }^{4}$.

\section{KASUS}

Pasien wanita usia 22 tahun, suku jawa, pasien mengeluh bibir terasa kering, kaku dan panas. Dari anamnesis diketahui pasien memakai lipstik dan pelembab baru merek "R" sejak 2 minggu yang lalu. Sejak seminggu yang lalu pasien merasa gatal, kemudian kaku dan kering, tapi pasien mengabaikan. Lipstick dan pelembab terus digunakan, pasien belum memakai obat apapun untuk menghilangkan keluhannya. Pasien mengaku baik dirinya maupun keluarganya tidak mempunyai riwayat alergi. Keadaan umum pasien baik.

Dari pemeriksaan klinis ekstra oral, kelenjar submentalis pada palpasi teraba, kenyal dan tidak sakit, dapat digerakkan. Pada merah bibir dan sudut bibir tampak deskuamasi, fisura, eritematous, ada bagian yang erosi dan sakit. Pada pemeriksaan intra oral tidak tampak adanya kelainan. Diagnosis klinis suspek allergic contact cheilitis karena pemakaian lipstick, diagnosis banding adalah exfoliative cheilitis

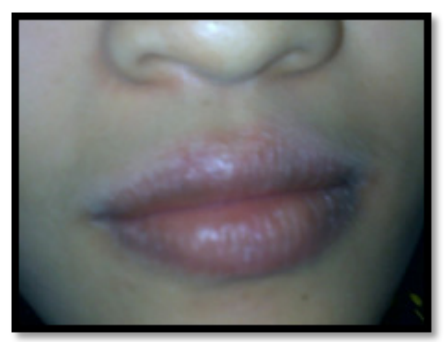

Gambar 1. Merah bibir atas-bawah dan sudut mulut tampak inflamasi, deskuamasi, fisura, erosif. 
Pasien diberi resep obat anti inflamasi nonsteroid topical yaitu aloclair gel (aplikasinya dengan cara dioleskan pada vermillion dan sudut mulut $4 x /$ hari) dan multivitamin. Pasien dianjurkan menggunakan obat secara teratur, menghindari penggunaan lipstik yang baru (merk "R") ataupun yang lain, menghindari makanan yang pedas, panas dan bergetah serta jangan menjilati bibirnya. Pasien dirujuk untuk pemeriksaan darah lengkap, IgE total dan rencana dilakukan patch-test. Pasien disarankan kontrol setelah ada hasil pemeriksaan dari lab.

\section{Kunjungan ke-2 ( 1 hari kemudian)}

Pada kunjungan ke-2 ini, pasien masih mengeluh pada bibirnya terasa kaku dan sakit, serta ada sedikit rasa panas. Pada pemeriksaan klinis, kelenjar limfe submentalis teraba, kenyal, tidak sakit, suhu dan warna normal. Merah bibir dan sudut bibir masih tampak inflamasi, deskuamasi, fisura, sakit dan ada sebagian yang erosi. Obat di-instruksikan digunakan sesuai aturan.

Hasil pemeriksaan lab, IgE total 10 ( $\mathrm{N}<$ $100 \mathrm{IU} / \mathrm{mL}$ ), basofil 2\% ( $: 0-1 \%$ ) dan limfosit $40 \%$ (N: $25-35 \%$ ). Hasil pemeriksaan yang lain dalam keadaan normal.

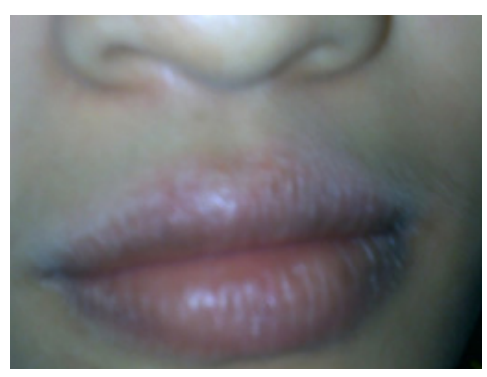

Gambar 2. Merah bibir atas-bawah dan sudut mulut tampak inflamasi, deskuamasi, fisura, erosif.

Pasien disarankan untuk tetap meneruskan pengobatan yang telah diberikan dan digunakan secara teratur. Menghentikan pemakaian lipstick dan pelembab merk "R" yang diduga sebagai allergen maupun merk yang lain, menghindari makanan yang merangsang (pedas, panas dan bergetah) dan dilarang menjilat bibir. Pasien dirujuk ke poli kulit-kelamin untuk dilakukan patch-test, dan kontrol setelah ada hasil dari poli kulit-kelamin.

Kunjungan ke-3 (6 hari kemudian).

Pada kunjungan ke-3 ini pasien merasa lebih baik, masih ada keluhan sakit pada bibir bawah, masih ada rasa kaku tapi tidak rasa kering. Pasien menggunakan obat secara teratur sesuai petunjuk dokter, pasien juga tidak menggunakan lipstick merek apapun. Secara klinis pada vermillion atas tampak normal tapi pada vermillion bawah tampak inflamasi, deskuamasi, fisura dan erosi. Pasien diinstruksikan untuk melanjutkan pengobatan dan menghindari makanan merangsang, menghindari penggunaan lipstick dan pelembab merk apapun serta tidak boleh menjilat bibir. Patch test masih belum dilakukan karena keterbatasan waktu dari pasien.

Kunjungan ke-4 (12 hari kemudian).

Pada kunjungan yang ke-4 ini pasien sudah merasa jauh lebih baik. Bibir bawah sudah lebih nyaman, tapi masih ada rasa kaku. Obat dan instruksi sudah dijalankan. Pemeriksaan ekstra oral didapatkan bibir bawah tampak fisura, tidak sakit, kering. Pada pasien akan dilakukan pemeriksaan patch test untuk memastikan diagnosa dan penyebab dari penyakit ini. Pemeriksaan patch-test tidak dilakukan di bagian kulit-kelamin , tapi dilakukan di FKG Unair bagian penyakit mulut dibawah persetujuan \& pengawasan Spesialis kulit kelamin RSUD Dr. Soetomo dengan alergen yang digunakan berupa lipstik dan pelembab 
yang telah dipakai oleh pasien dengan lokasi pada punggung pasien. Pembacaan hasil dari patch test ini dapat dilihat berdasarkan tabel dibawah ini ${ }^{5}$

Tabel 1. Hasil pemeriksaan patch test (Maibach H.I, Lachapelle J.M. 2009)

\begin{tabular}{ll}
\hline+ & Negative \\
+ & Only erythema, questionable \\
++ & Erythema, infiltration \\
++ & Erythema, few papules \\
& Erythema, many or spreading \\
+++ & papules \\
\hline
\end{tabular}

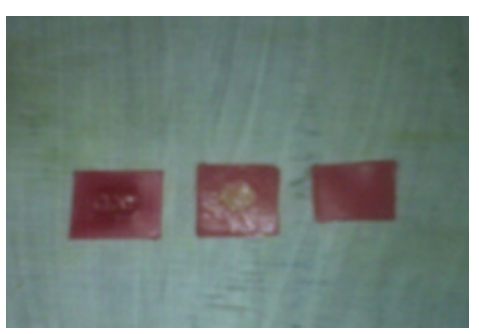

Gambar 3. Patch test yang dilakukan pada pasien.

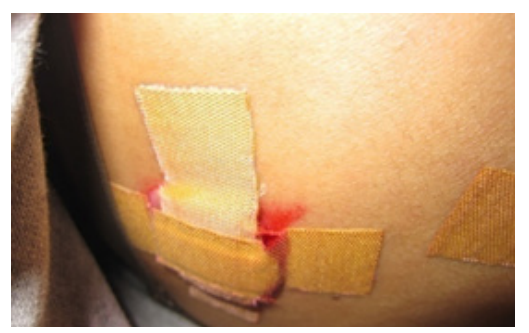

Gambar 4. Bahan kosmetik untuk patch test.

Kemudian bahan ini ditempelkan dalam bentuk kontak langsung dengan kulit dan biasanya pada punggung bagian atas (agar terhindar dari sinar matahari / UV). Pembacaan hasil test ini dilakukan setelah 48 jam kemudian. Selama 48 jam tidak boleh membersihkan bagian itu atau melakukan olahraga yang kuat, karena jika pita perekat terlepas maka proses test ini harus diulang. Test ini juga ini tidak boleh terkena sinar matahari atau sumber sinar ultraviolet (UV). Setelah 48 jam, patch mulai dikeluarkan dan pembacaan dlakukan 1 jam kemudian. ${ }^{5,6}$

Patch test ini mencakup aplikasi berbagai zat uji pada kulit di bawah pita perekat yang kemudian didiamkan selama 48 jam. Test ini dilakukan pada sisi kulit yang tidak timbul lesi alergi. Dalam kasus ini, pemeriksaan patch test ini menggunakan bahan alergen berupa lipstik dan pelembab yang diduga mengadung nikel serta juga diduga sebagai penyebab dari kelainan ini. Pemeriksaan patch test dilakukan pada punggung penderita karena pada bagian tubuh ini (punggung) merupakan daerah yang paling aman yang terlindungi dari paparan sinar matahari / sinar ultraviolet (UV). Pasien diberikan instruksi tidak boleh terkena air bagian patch test (punggung), tidak boleh mengkonsumsi makanan yang merangsang (pedas, panas, dan bergetah), tidak boleh menjilat bibir dan banyak mengkonsumsi sayur-sayuran serta buah-buahan.

Kunjungan ke-5 (14 hari kemudian)

Pada kunjungan ini pasien tidak merasakan keluhan pada bibirnya, secara klinis bibir tampak normal. Oleh dokter Spesialis KulitKelamin diberikan antihistamin (cetirizine 1xhari selama 5 hari) untuk mengobati lesi pada punggungnya akibat dari hasil patch test yang telah dilakukan. Semua obat dihentikan pemakaiannya kecuali ceterizine. 

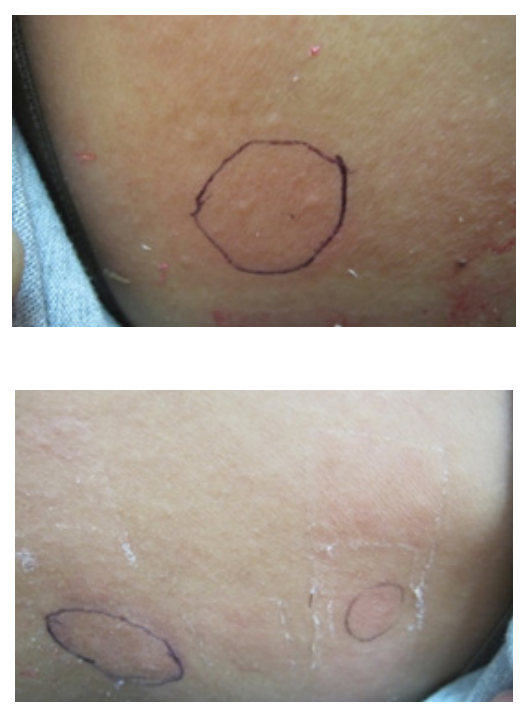

Gambar 5 dan 6 : Hasil pacht-test setelah 48 jam.

\section{DISKUSI}

Wanita usia 22 tahun, suku jawa, mengeluh bibir terasa kering, kaku dan panas. Pasien memakai lipstik dan pelembab baru merek "R" sudah 2 minggu yang lalu. Sejak seminggu yang lalu pasien merasa gatal, kaku dan kering, tapi pasien mengabaikan, karena lipstick dan pelembab terus digunakan, pasien belum memakai obat apapun. Dari pengakuan pasien, baik diri maupun keluarganya tidak mempunyai riwayat alergi. Keadaan umum pasien baik. Pada merah bibir dan sudut bibir tampak deskuamasi, fisura, eritematous, erosi dan sakit. Pada pemeriksaan intra oral tidak tampak adanya kelainan. Diagnosis klinis suspek allegic contact cheilitis karena pemakaian lipstick, diagnosis banding adalah exfoliative cheilitis.

Gambaran klinis dari allergic contact cheilitis adalah keradangan pada vermillion atau kulit disekitarnya, bisa bibir bawah/atas atau keduanya dan bisa melibatkan sudut mulut. Pada vermillion tampak kemerahan, kering, deskuamasi dan berfisur. Allergic contact cheilitis jarang melibatkan mukosa labial. Pasien mengeluh kaku, gatal, panas dan sakit pada bibirnya ${ }^{4}$.

Dianosis banding dari kasus diatas adalah exfoliative cheilitis yang mempunyai gambaran klinis sangat mirip. Exfoliative Cheilitis adalah kondisi radang kronik pada bibir yang ditandai dengan deskuamasi, fisura, kering , adanya rasa terbakar dan sakit. Bibir selalu terlihat kemerahan sebagai tanda inflamasi ${ }^{7}$.

Pasien diberi resep obat anti inflamasi non-steroid topical (aloe vera extract gel $8 \mathrm{ml}$ tube No.I) dan multivitamin, menghindari penggunaan lipstik dan pelembab yang baru (merk "R") ataupun merek yang lain, menghindari makanan yang pedas, panas dan bergetah serta jangan menjilati bibirnya. Pasien dirujuk untuk pemeriksaan darah lengkap, IgE total dan rencana dilakukan patch-test.

Terapi suportif yang diberikan mengandung vit C 750 mg dan vit B12 12 mg. Fungsi utama Vitamin $C$ berperan dalam pembentukan kolagen, pro-teoglikan dan bahan-bahan organik lain pada bagian antarsel dan lamina propia. Fungsi vitamin $C$ akan meningkat bila terjadi kerusakan jaringan. Vitamin B12 penting dalam sintesa asam nukleat dan myelin, sehingga dengan demikian mempengaruhi pematangan sel. . $^{8,9}$ Aloe vera extract gel mempunyai efek terapeutik sebagai antiinflamasi topikal dan antiseptik, dengan bahan dasarnya yang berupa gel dapat memudahkan pasien untuk mengaplikasikan obat pada daerah yang beradang ${ }^{10}$.

Pada kunjungan kedua (sehari berikutnya) pasien merasabibirnya masih terasakaku (agak berkurang) dan pada pemeriksaan ekstra oral belum ada perubahan. Pasien datang dengan membawa hasil pemeriksaan penunjang (laboratorium). Hasil lab menunjukkan basofil $2 \%(N=0-1 \%)$ dan limfosit 40\% ( $N=25-35 \%)$ yang menandakan adanya proses inflamasi 
dan infeksi kronik, yang dalam kasus ini terjadi pada daerah bibir. Selain itu nilai IgEtotal dalam batas normal yaitu $10 \mathrm{IU} / \mathrm{mL}(\mathrm{N}<$ $100 \mathrm{IU} / \mathrm{mL}$ ) yang berarti tidak adanya reaksi hipersensitivitas yang melibatkan Ig-E.

Pada pasien juga dilakukan patch test untuk menegakkan diagnosa secara pasti dan menentukan alergen penyebab dari penyakit ini. Dari pemeriksaan patch test ini didapatkan hasil berupa eritema dan terdapat beberapa papula yang berarti positif +2 . Pasien juga mengeluhkan rasa gatal pada kulit pasca patch test ${ }^{5}$. Dapat disimpulkan bahwa pasien positif terkena alergi kontak dengan alergen bahan kosmetik (lipstik dan pelembabnya) yang mengandung nikel sebesar 3,32ppm dan baru dipakainya selama 2 minggu ini. 8,15 Telah ada sumber yang menyebutkan bahwa lipstik menjadi alergen dari bahan kosmetik yang tersering sebagai penyebab reaksi hipersensitifitas ${ }^{1}$.

Pada lipstick, nickel sulfate dexyhidrate digunakan untuk campuran dalam komposisi warna yang dapat membuat lipstick menjadi lebih tahan lama melekat pada bibir, selain itu nikel juga digunakan untuk melapisi kemasan (lipstick holder). Menurut FDA (food drugs administraton) Amerika, kandungan nikel yang boleh digunakan untuk bahan kosmetik adalah 0.600-5.947 ppm. Kandungan nikel diatas $1 \mathrm{ppm}$ dapat menyebabkan reaksi alergi. Penelitian Chauhan dkk (2014) pada beberapa lipstick di pasaran India, menunjukkan bahwa lipstick dengan harga yang murah dan berwarna lebih menarik (merah dan pink) mengandung lebih banyak nickel sulfate dexyhidrate dari pada yang dijinkan. Selain itu kemasan metal pada lipstick holder juga terbukti mengandung logam ini, yang menimbulkan banyakkeluhan reaksi alergi ${ }^{11,12}$

Allergic Contact Cheilitis merupakan allergic contact dermatitis yang mengenai bibir. Hal ini merupakan reaksi dari hipersensitivitas tipe IV yang melalui kontak dengan alergen dan biasanya merupakan keradangan yang mengenai vermillion border atau kulit disekitarnya (peri-oral). Alergi kontak adalah tipe delayed hypersensitivity yang mana timbul setelah kulit/mukosa kontak dengan alergen ${ }^{1}$. Alergen tersebut merupakan molekul kecil yang sangat reaktif (dalam hal ini adalah ion metal dari nikel yaitu $\mathrm{Ni2+}$ ) yang dapat dengan mudah menembus kulit/mukosa yang intact. Pada kontak pertama (initiation phase) setelah diabsorbsi kedalam epitel substansi tersebut akan berikatan dengan protein (karier) dan menjadi immunogenic. Kompleks antigenkarier di fagosit oleh sel Langerhans kemudian sel Langerhans akan bermigrasi ke limfe-node dan mengaktifkan $T$ cells, bersama dengan molekul MHCII akan menstimulasi memori CD4+ T cells ${ }^{1,2}$.

Pada kontak yang berulang dengan antigen yang sama (elicitation phase), sel Langehans akan mengaktivasi memori CD4+ limfosit di lamina propria. Aktivasi limfosit akan mensekresi berbagai sitokin, antara lain interferon gama dan IL-17. Stimulasi pada keratinosit akan menyebabkan sel epitel melepaskan IL-1, IL-6, TNF-à, GM-CSF, chemokin CXCL8, dan interferon yang menginduced chemokin CXCL-11, CXCL-10 dan CXCL9. Sitokin dan chemokin meningkatkan respon inflamatori dengan meng-induced migrasi monosit kedalam lesi dan menjadi makrofag yang bisa menarik lebih banyak sel-T 1,2. Secara klinis reaksi akan terlihat sesudah 48-72 jam dan sesudah periode ini secara gradually akan menurun disebabkan kontribusi PGE yang disekresi oleh makrofag, keratinosit dan IL-10 ${ }^{1}$.

Hasil pemeriksaan lgE normal, hal ini 
menunjukkan dalam sirkulasi darah tidak ada peningkatan kadar lgE. Berart kasus diatas adalah reaksi hipersensitivitas type IVa yang tidak melibatkan IgE tapi melibatkan aktivasi makrofag ${ }^{2}$. Bila hasil pemeriksaan IgE menunjukkan kadar yang lebih tinggi dari normal maka berarti pasien tersebut juga menderita atopic dermatitis.

Setelah dilakukan patch test, oleh dokter spesialis kulit-kelamin bagian SMF kulitkelamin RSUD DR.Soetomo diberikan obat antihistamin $\left(\mathrm{AH}_{1}\right)$ berupa ceterizine untuk mengatasi rasa gatal dan mengobati lesi yang terjadi akibat dari patch test ini. Efeknya bersifat paliatif, membatasi dan menghambat aktivitas farmakologi histamin yang dilepaskan sewaktu reaksi antigen-antibodi terjadi. $\mathrm{AH}_{1}$ sangat berguna untuk mengobati alergi (seperti urtikaria). $\mathrm{AH}_{1}$ merupakan salah satu obat terbanyak dan terluas digunakan di seluruh dunia.Cetirizine merupakan metabolit aktif asam karboksilat dari antagonis reseptor $\mathrm{H}_{1}$ generasi pertama yaitu hidroksizin. Cetirizine merupakan antihistamin yang sangat kuat dan spesifik. Cetirizine merupakan antagonis reseptor histamin-1 $\left(\mathrm{H}_{1}\right)$ generasi kedua yang aman digunakan pada terapi alergi. Selain mempunyai efek antihistamin, cetirizine juga mempunyai efek anti-inflamasi melalui penghambatan kemotaksis sel inflamasi ${ }^{13}$.

\section{DAFTAR PUSTAKA}

1. Bakula A. Lugovic-Mihic L. Situm M. Turcin J. Sinkovic A. Contact Allergy In The Mouth: Diversity of Clinical Presentations And Diagnosis of Common Allrgens Relevant to Dental Practice. Acta Clinical Croat. 2011; 50:553-561.

2. Murphy K. Travers P. Walport M. Allergy and Hypersensitivity. Janeway's. Immunobiology. 7ed. Garland Science; 2008.p. 555-598.

3. Axéll T. Hypersensitivity of the oral mucosa: clinics and pathology. Acta Odontol Scand. 2001 Oct;Vol. 59, No.5. p. 315-9.

4. Allergic contact cheilitis. Author: Dr Delwyn Dyall-
Smith FACD, Dermatologist, 2010. DermNet New Zealand. Available at: www.dermnetnz.org/topics/ allergic-contact-cheilitis/

5. Maibach H.I, Lachapelle J.M. Patch Testing and Prick Testing. A Practical Guide Official Publication of the ICDRG. 2nd edition. Springer-Verlag Berlin Heidelberg. 2009. p: 121-127.

6. Lewis V. juli 2011. Patch Teting for Skin Allergies. Netdoctor. Available at http://www.netdoctor.co.uk/ health_advice/examinations/patchtesting.htm Diakses pada agustus 2012. (16-Yoli)

7. Exfoliative Cheilitis Available at : healthylifemed. com/exfoliative-cheilitis/Jun 23, 2015

8. Becom-Zet. 2011. We care pharmacy. Available at http://www.farmasiku.com/index. php?target=products\&product_id=30063 Diakses pada agustus 2012.

9. Vanek V.W, Borum P, buchman A. 2012. A.S.P.E.N. Position paper : Recommendtion for Changes in Commercially Available Parenteral Multivitamin and Multi-Trace Element Product. The American Society for Parenteral and Enteral Nutrition. Vol: 27:4. p: 440-491.

10. www.aloclairplus.co.uk/ Aloclair @Plus mouth ulcer relief. Diakses 19 Sept.2016

11. Bukhari, Khalid A. Determination of lead, cadmium, chromium and nickel in different brand of lipstick. Internatuonal Journalof Biology, Pharmacy and Allied Science. 2013 ; 2(5). 1003-1009

12. Chaucan, Chandak and Agrawal. Evaluation of heavy metals contamination in marketed lipstick. Internatonal Journal of advanced research. 2012. Vol.2 ; issue 4, 257-262.

13. www.drugs.com , Drugs A to Z. Cetirizine $\mathrm{Hcl}$. Diakses 19 sept 2016 